
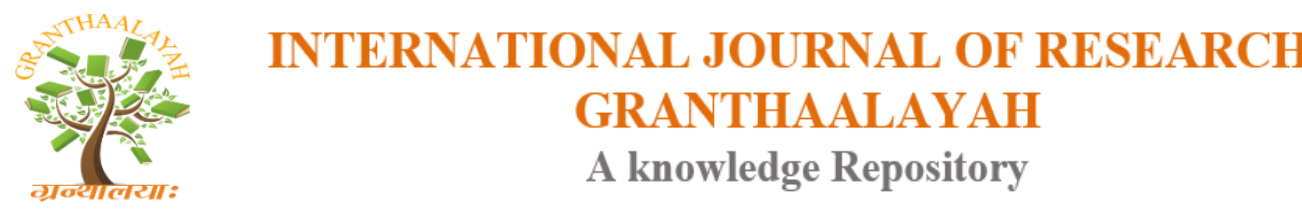

Science

\title{
IDENTIFICATION AND MAPPING OF HOT SPOT AREAS SUSCEPTIBLE TO SOIL EROSION IN ERAK AL KARAK AREA USING GEOINFORMATICS
}

\author{
Safa Mazahreh *1, Mohammad Alkharabsheh ${ }^{2}$, Majed Bsoul ${ }^{2}$, Doaa Abu Hammor ${ }^{1}$, \\ Lubna Al Mahasneh 1 \\ ${ }^{* 1}$ Environment and Climate Change Research Directorate, NARC, Jordan \\ ${ }^{2}$ Water and Soil Research Directorate, NARC, Jordan
}

\begin{abstract}
Jordan is a country dominated by arid climate and fragile ecological system, where $91 \%$ is classified as arid land with annual average rainfall rarely exceeds $200 \mathrm{~mm} / \mathrm{y}$. Therefore, land degradation, soil erosion and desertification are important areas of interest, where soil erosion is considered one of the major causes for land degradation in Jordan. The main objective of this study is to create an erosion hazard map and identify the areas susceptible to soil erosion in Erak Al karak watershed in southern part of Jordan. Soil erosion model RUSLE with the integration of GIS tools has been developed to estimate the annual soil loss. The estimated mean annual soil loss is (38.7 ton/ ha/year). The erosion map produced highlighted the hot spot areas susceptible to soil erosion. A relationship was obvious between terraces land use and soil loss, where $22 \%$ of the soil loss was reduced by applying soil conservation technique (terraces). According to this model, most of the hot spot areas are located in the rangeland 63\% while the agricultural areas are responsible for $14 \%$ of the hot spot areas. The results emphasis the importance of urgent land use planning and conservation practices to reduce the impact of soil erosion.
\end{abstract}

Keywords: Erosion; RUSLE; GIS; Land Degradation; Hot Spot.

Cite This Article: Safa Mazahreh, Mohammad Alkharabsheh, Majed Bsoul, Doaa Abu Hammor, and Lubna Al Mahasneh. (2018). "IDENTIFICATION AND MAPPING OF HOT SPOT AREAS SUSCEPTIBLE TO SOIL EROSION IN ERAK AL KARAK AREA USING GEOINFORMATICS." International Journal of Research - Granthaalayah, 6(6), 246-259. https://doi.org/10.29121/granthaalayah.v6.i6.2018.1371.

\section{Introduction}

Jordan is situated in the dry region of the eastern Mediterranean Sea. Its area approximates 89,000 $\mathrm{Km}^{2}$, of which $91 \%$ is classified as arid land, where the annual average rainfall rarely exceeds 200 $\mathrm{mm} / \mathrm{y}$. In Jordan, several studies have shown that the country is at risk of Land degradation due to high population growth, desertification, deforestation, soil erosion and intensive cultivation. Jordan could face decreasing water supplies, viable farmland and food, if the arid and semi-arid 
lands of the country suffer from further degradation and become more desert-like $(1,2,3)$. The main issue concerning environmental problems is the accelerated degradation of vegetation, soil and the current rate of agricultural land degradation world-wide by soil.

Soil degradation by erosion is a serious environmental problem in the highlands region of Jordan, resulting topsoil loss and declining soil quality and productivity. Soil erosion is the process of dislodgement and transport of soil particles from the surface by water and wind. The soil particles can be moved by the energy expended at the soil surface by the raindrops and then transported by water, wind or the force of gravity, (7). When the rate of rainfall exceeds the infiltration rate on slopes, surface runoff occurs potentially causing rill erosion while when combined with the raindrops splashing erosion and sheet erosion it results in a large amount of soil loss. Several studies were carried out to estimate soil erosion in Jordan and its impact at different scales (4, 5, and 6). Many different models have been developed to describe and predict soil erosion by water and associated sediment yield. They vary considerably in their objectives, time and spatial scales involved. Among them is the Revised Universal Soil Loss model RUSLE which was chosen because it represents the effects of rainfall, soils, terrain and management practices on soil loss.

In the process of soil erosion, nutrients rich top soil loss and prediction of soil erosion hazard are vital for effective soil conservation planning of a watershed for sustainable development. As a result, the prevention of soil erosion relies on selecting appropriate strategies for soil conservation and this, in turn, requires an understanding of the processes of erosion.

The uses of Remote sensing and GIS technologies have proved successful in many fields of natural resources management. The ability of GIS to collect, store and manipulate various types of data in a unique spatial database, helps performing various kinds of analysis and thus, extracting information about spatially distributed phenomena.

The integrated use of remote sensing and GIS could help to assess soil loss at various scales and also to identify areas that are at potential risk of soil erosion. Several studies showed the potential utility of GIS technique for quantitatively assessing soil erosion hazard based on various models. The combined use of GIS and RUSLE has been proved to be an effective approach for estimating the magnitude and spatial distribution of erosion.

This Research aims to estimate the soil erosion by water using RUSLE method in GIS Environment to create a potential erosion map and identify and map the areas susceptible to soil erosion. This study estimates the soil erosion by water using RUSLE method to create a potential erosion map for Erak Al karak. The RUSLE model was chosen because it represents the effects of rainfall, soils, and terrain and management practices on soil loss 7.

\section{Materials and Methods}

\subsection{Study Area}

The pilot area (Erak Village) is located $30 \mathrm{~km}$ south of Al-Karak, $10 \mathrm{~km}$ west of Mu ta town figure (1). The area of the watershed is $30 \mathrm{~km}^{2}$. The parent material is primarily colluviums derived from limestone, moderately deep stony to shallow, very common stones and boulders with $>20 \%$ rock 
outcrop. The topography is dominated by an undulating to rolling dissected plateau with slope of 0 to more than $80 \%$. The watershed is characterized by Thermic temperature regime and Xeric moisture regime with annual rainfall ranges between 300 to $350 \mathrm{~mm}$ whereas altitude ranges between $86-1283 \mathrm{~m}$ above sea level.
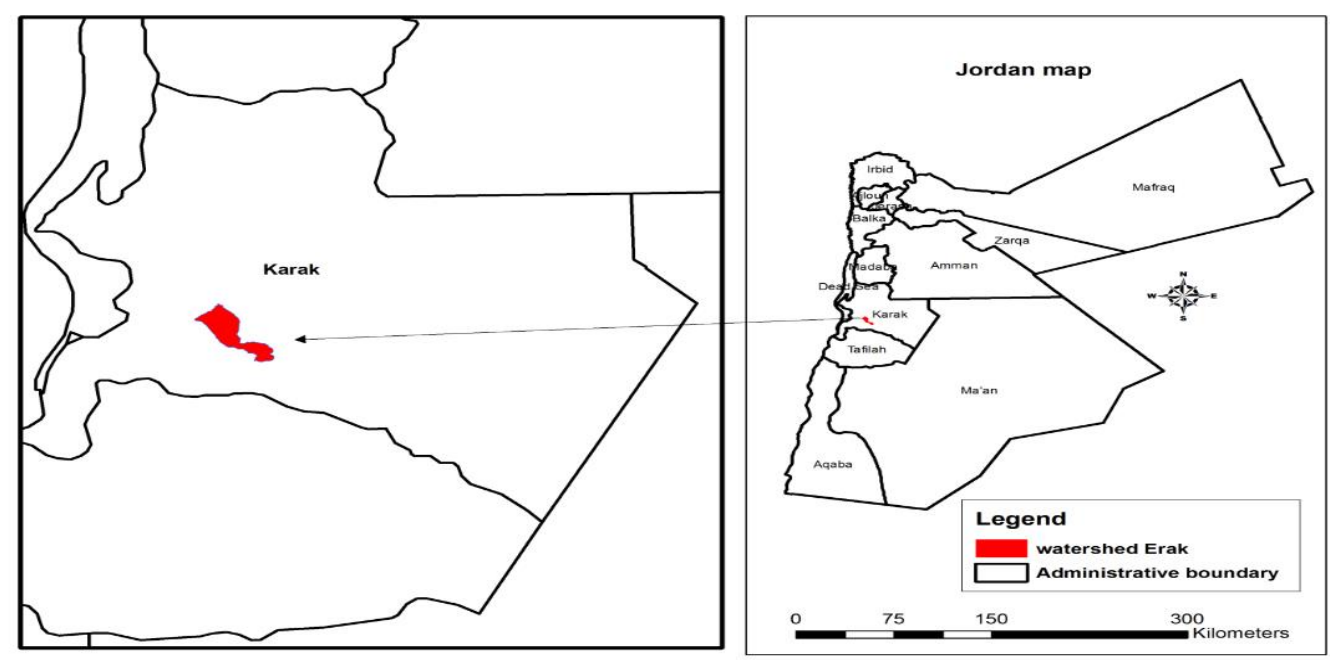

Figure 1: Location of Erak study in Jordan

\subsection{RUSLE Data Sets}

Soil erosion is affected by different factors including rainfall, soil types and texture, topography and land use. These factors can be represented using the GIS techniques. In order to predict the soil erosion, the following spatial and temporal datasets are used:

\subsubsection{Digital Elevation Model (DEM) of 30 M Resolution Figure (2), Was Used to Derive the Slope Map}

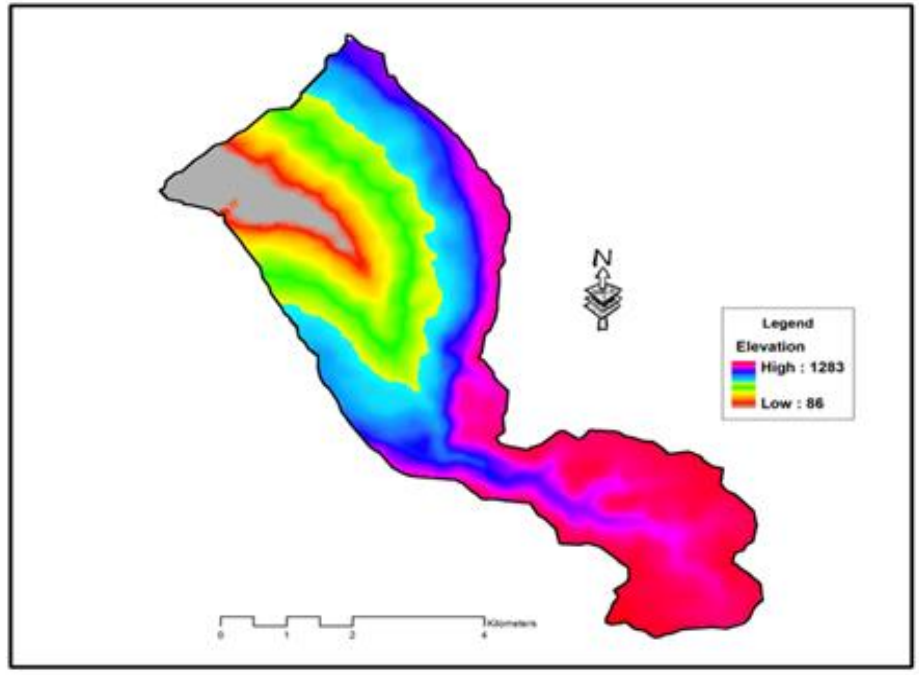

Figure 2: Digital Elevation Model (DEM) 


\subsubsection{Current Land Use Map}

A World View satellite image, (April, 2011), with resolution $50 \mathrm{~cm}$ was used to map existing land use (Source: GIS unit NCARE). The image was classified into land use classes based on Corine classification system using level 3 of details. Based on the experience gained in the field survey of Erak study area, three classes have been added to Erak land use classes which are absent in the Corine classification system: bare soil, bare rock, and terraces. As a result, figure (3) shows the current land use map.

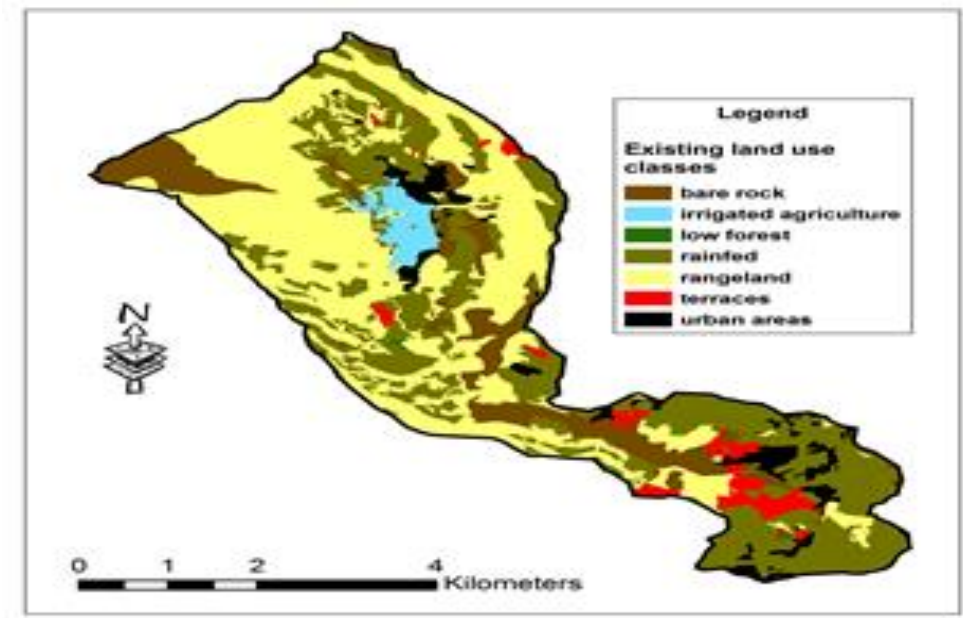

Figure 3: Current land use map

\subsubsection{Rainfall Data}

Long term rainfall data (1975-2010) from Jordan metrological department was presented as Rainfall map and interpolated using Arc map. Figure (4) shows the annual rainfall isohyets for the study area.

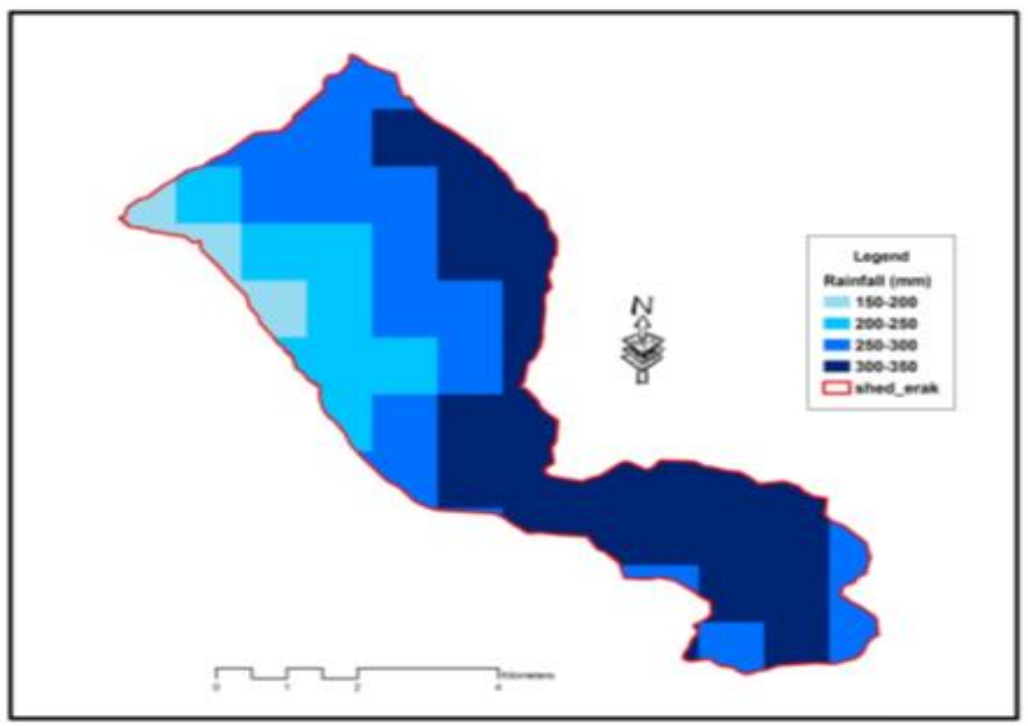

Figure 4: Annual rainfall isohyets 


\subsubsection{Satellite Images Dataset}

In this study, Landsat 8 which is an American Earth observation satellite launched on February 11, 2013 satellite images are used to estimate the $C$ factor in the study area. Three Landsat 8 satellite images in selected times $(28 / 11 / 2014$, 5/4/2015and 31/1/2015) were downloaded from website (http://www.earthexplorer.usgs.gov).

\subsubsection{Soil Survey Observations}

More than 175 soil observations distributed all over the study area, collected and analyzed by NCARE in past projects, were used to estimate the $\mathrm{K}$ factor as shown in figure (5).

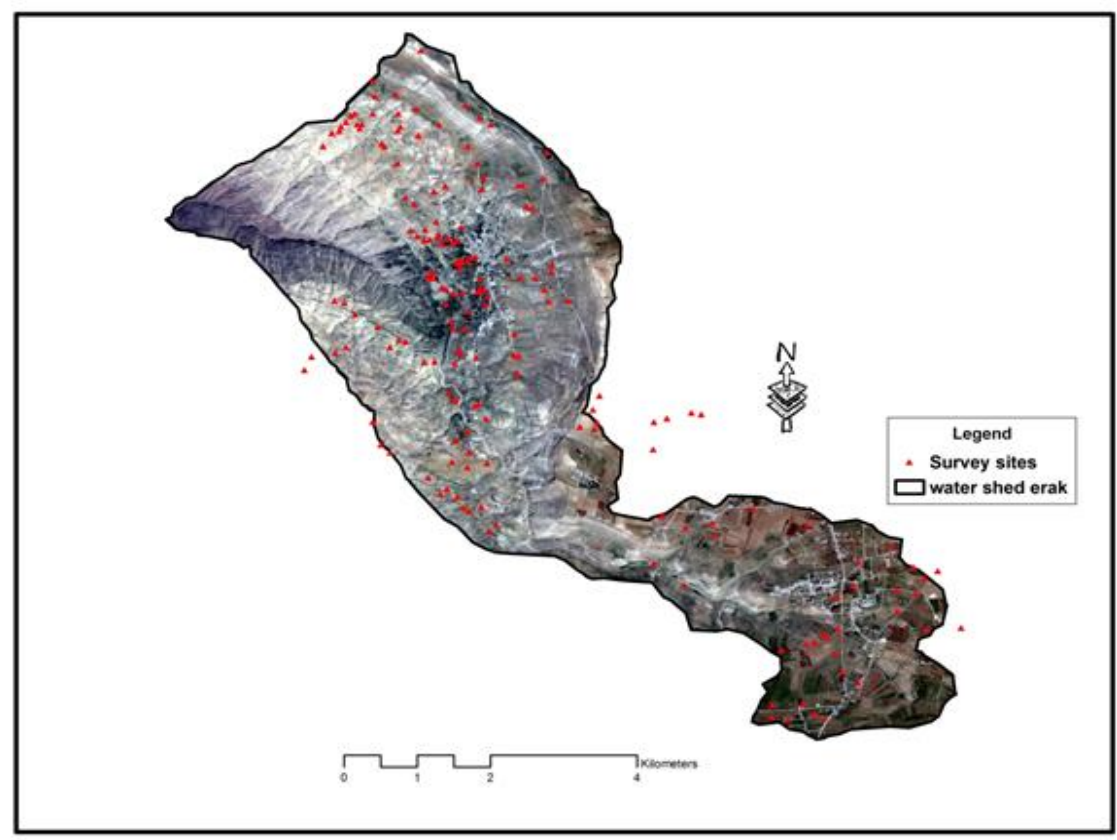

Figure 5: Soil survey observations

\section{RUSLE Parameters}

In 1985, the US Department of Agriculture (USDA) decided that the Universal Soil Loss Equation (USLE) developed by Wischmeier and Smith (1958) (9) should be revised to incorporate additional research, resulting in a modified version called the Revised RULSE (8). RUSLE is an erosion model designed to predict the long-term average annual soil loss carried by runoff from specific field slopes in specified cropping and management systems including rangeland (8). The RUSLE model groups the erosion process into five categories including climate, soil profile, relief, vegetation/ land use, and Land management practices. The parameters of RUSLE were estimated based on the DEM, field observations, land use map, rainfall, and NDVI.

The model takes the form:

$$
\boldsymbol{A}=\boldsymbol{R} \times \boldsymbol{K} \times(\boldsymbol{L} \times \boldsymbol{S}) \times \boldsymbol{C} \times \boldsymbol{P}
$$


Where:

$\mathrm{A}=$ computed spatial average soil loss and temporal average soil loss per unit of area; (ton ha-1 year1)

$\mathrm{R}$ = rainfall-runoff erosivity factor; [MJ mm, (ha-1 h-1 year-1)]

$\mathrm{K}=$ soil erodibility factor; [ton ha- $1 \mathrm{~h} \mathrm{MJ}-1 \mathrm{ha}-1 \mathrm{~mm}-1)$ ]

$\mathrm{L}=$ slope length factor; (dimensionless)

$\mathrm{S}=$ slope steepness factor; (dimensionless)

$\mathrm{C}=$ cover management factor; (dimensionless)

$\mathrm{P}=$ support practice factor (dimensionless)

\subsection{Rainfall Erosivity ( $R$ factor)}

$\mathrm{R}$ is a measure of Erosivity of rainfall (product of storm kinetic energy and maximum 30-minute intensity EI30) (10) and the Standard International (SI) unit for rainfall Erosivity is MJ.mm / (ha.h.yr). In this study, rainfall Erosivity factor (R) is estimated using Rainfall map prepared from twenty years long term rainfall data (1975-2010). El Taif et al. (2010) (11) developed an equation to estimate $\mathrm{R}$.

El Taif et al. (2010) equation $\ldots \ldots \ldots \ldots \ldots . . \mathrm{R}=23.61 \times e^{0.0048 p}$

Where $\mathrm{P}$ is the annual long-term rainfall $(\mathrm{mm})$

\subsection{Soil Erodibility Factor (K)}

Soil erodibility factor $(\mathrm{K})$ is defined as the rate of soil susceptibility to detachment and transport of soil particles under an amount and rate of runoff for a specific storm event Soil. Soil texture (sand, clay, silt, very fine sand), organic matter, structure type and permeability determine the Erodibility of a particular soil [20]. The K factor was evaluated and determined using the Nomograph developed by (Wischmeier 1971; Wischmeier and Smith 1978) $(12,13)$.

The $\mathrm{K}$ factor was computed using the following equation based on the Wischmeier and Smith 1978 Nomograph while soil lab analysis of the field observations were used as inputs for the equation below.

$K=27.66 m^{1.14} \times 10-8 \times(12-a)+0.0043 \times(b-2)+0.0033 \times(c-3)$

Where $\mathrm{K}$ is the soil erodibility factor (ton ha h ha- 1 -MJ-1 mm-1)

$\mathrm{m}$ : is particle size parameter $(\%$ silt $+\%$ very fine sand $) *(100-\%$ clay $)$

a: is the organic matter content (\%)

b: is soil structure code used in soil classification

c: is the soil permeability class.

The soil structure index (b) is equal to: 1 for very fine granular soil; 2 for fine granular soil; 3 for medium or coarse granular soil; 4 for blocky, platy, or massive soil. while the profile-permeability class factor (c) is equal to: 1 for very slow infiltration; 2 for slow infiltration; 3 for slow to moderate infiltration; 4 for moderate infiltration; 5 for moderate to rapid infiltration; 6 for rapid infiltration. 


\subsection{Slope Length and Steepness Factor (LS)}

The combined topographic (LS) factor was computed rather than the individual slope length and Slope angle, because the upstream contributing area is generally preferred instead of individual slope lengths. L and S are factors representing the topography of the land and they define the effects of slope angle and slope length on erosion. The slope length factor $\mathrm{L}$ is defined as the distance from the source of runoff to the point where deposition begins, or runoff becomes focused into a defined channel. Spatial Analyst Extension in GIS was used to compute LS factor.

The slope in degree, The Flow Direction and flow accumulation were derived from DEM to estimate the LS factor. In this study the model of semis 2003 (10) was used as below:

$$
\begin{aligned}
L S=P o w & ([\text { FlowAcc }]) \times \text { resolution } / 22.1,0.6) \\
& \times \operatorname{Pow}(\sin ([\text { Slope Degree }]) \times 0.01745) / 0.09,1.3)
\end{aligned}
$$

\subsection{The Support Practice (P Factor)}

The conservation practice factor $(\mathrm{P})$ in the RUSLE model is the ratio of soil loss using a specific support practice to the corresponding soil loss after up and down cultivation (14). To predict $\mathrm{P}$ factor, the existing land use map was used based on satellite image world view $(50-\mathrm{cm}$. terraces has direct impact on $\mathrm{P}$ factor. Therefore, we used this land use to predict $\mathrm{P}$ factor based on slope percentage. Different $\mathrm{P}$ factors were obtained for this landuse class as shown in table (1).

Table 1: P factor values for contour - farmed terraced field from Wischmeier and smith,1978(13)

\begin{tabular}{|l|l|}
\hline Land slope \% & $\begin{array}{l}\text { Farm planning Contour } \\
\text { P factor }\end{array}$ \\
\hline 1 to 2 & 0.6 \\
\hline 3 to 8 & 0.5 \\
\hline 9 to 12 & 0.6 \\
\hline 13 to 16 & 0.7 \\
\hline 17 to 20 & 0.8 \\
\hline 21 to 25 & 0.9 \\
\hline
\end{tabular}

\subsection{The Cover Management C Factor}

The C-factor is defined as the ratio of soil loss from land with specific vegetation to the corresponding soil loss from continuous fallow (Wischmeier \& Smith, 1978). Vegetation cover is the second most important factor that controls soil erosion risk. The value of $\mathrm{C}$ mainly depends on the vegetation's cover percentage and growth stage and It ranges from 0 (high plant cover) to 1 (bare soil).The Rusle uses five subfactors to calculate the $\mathrm{C}$ factor: residual effect of soil use (soil management); soil cover by plant canopy; soil cover by crop residues; roughness of soil surface; and soil moisture (Renard et al., 1997)(14).The normalized difference vegetation index (NDVI) is one of the main indices used for vegetation monitoring and assessment, which allows the monitoring of the surface spatial and temporal changes. Therefore, from NDVI values, some methods have been developed to estimate the Rusle $\mathrm{C}$ factor. The NDVI value varies between -1 and 1, where low values can be found at water bodies, bare soil and built-up areas. NDVI is 
positively correlated with the amount of green biomass, so it can be used to give an indication for differences in green vegetation coverage.

In this study, three Landsat 8 satellite images (28/11/2015, 31/1/2016 and 5/4/2016) were used to estimate the NDVI values because the satellite images during the rainy season are recommended to use, when soil erosion is strongly active and the vegetation cover is at its peak (16).

The mean value of the three images was used in the module developed by Van der Knijff et al., 1999(15) to calculate the C factor.

NDVI-values were scaled to approximate C-values using the following provisional formula:

$$
C=\alpha \times N D V I /((\beta-N D V I))
$$

Where $\alpha, \beta$ Parameters that determine the shape of the NDVI-C curve, the value of $\alpha$ is 2 and the $\beta$ value is 1 (15).

\section{Results and Discussion}

\subsection{RUSLE Factors}

\subsubsection{Rainfall Erosivity (R factor)}

Figure (6) shows the values of R factor which range between 46 to123 (MJ.mm / ha.h.yr).

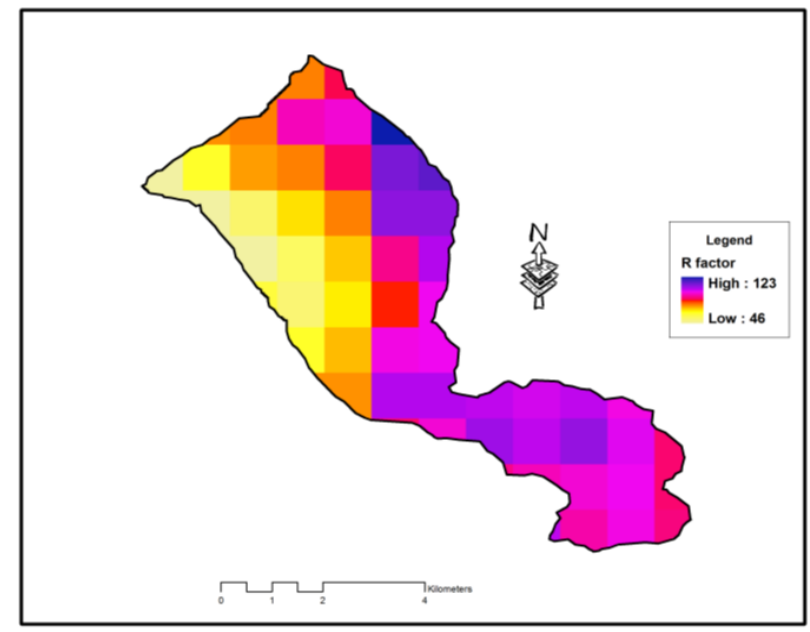

Figure 6: R factor

\subsubsection{Soil Erodibility Factor (K)}

Figure (7) shows the K factor which ranges between 0.02 to 0.05 (t. h/Mj.hr.mm). 


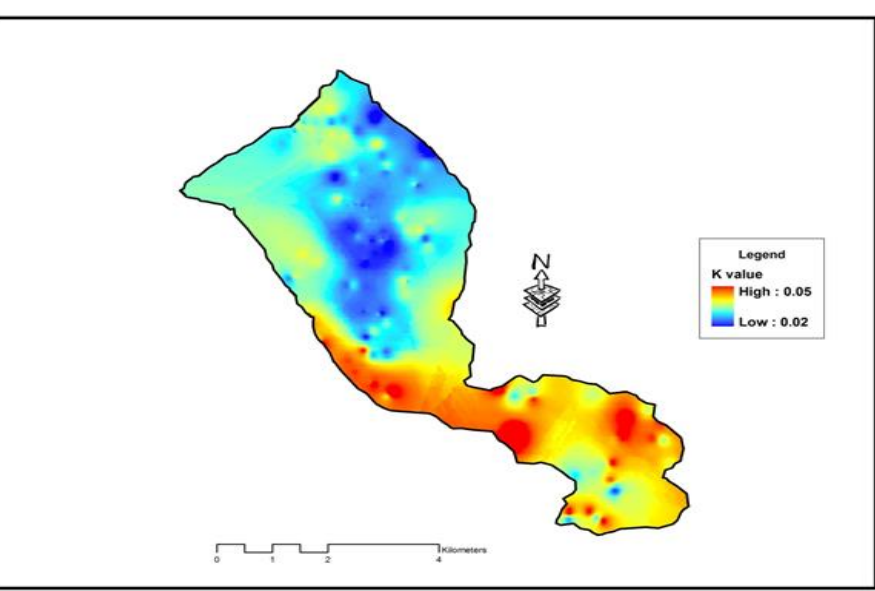

DOI: 10.5281/zenodo.1308937

Figure 7: K factor

\subsubsection{Slope Length and Steepness Factor (LS)}

Figure (8) shows the LS factor which ranges between 0 to 300.

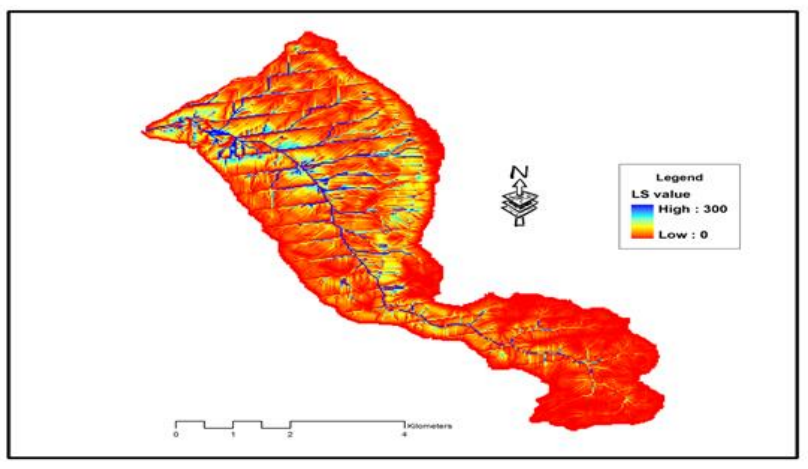

Figure 8: LS factor

\subsubsection{The Support Practice (P Factor)}

$\mathrm{P}$ is the support or land management practice factor. Figure (9) shows the P factor values which range between $0.5-1$.

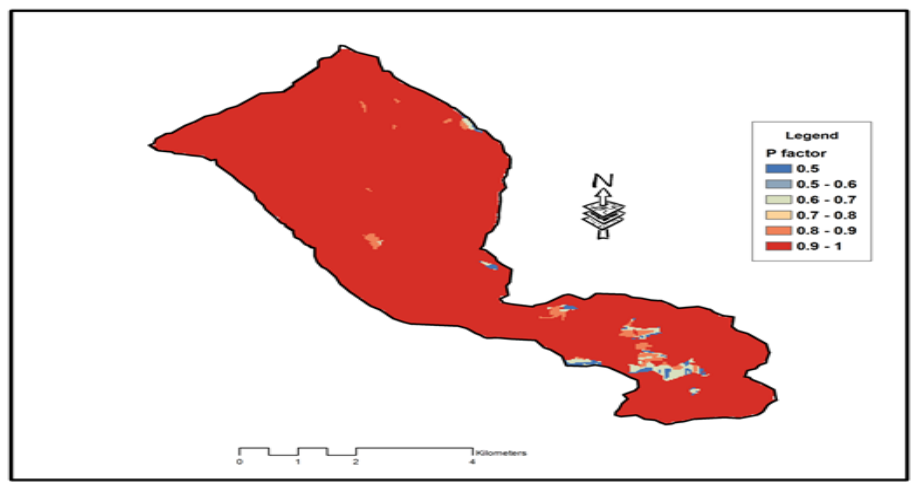

Figure (9): $\mathrm{P}$ factor 


\subsubsection{The Land Cover Management C Factor}

Figure (10) shows the NDVI Images captured in (28/11/2014, 31/1/2015 and 5/4/2015). These images were used to calculate the $\mathrm{C}$ factor. The $\mathrm{C}$ factor ranges between 0.3 to 1 as shown in figure (11).
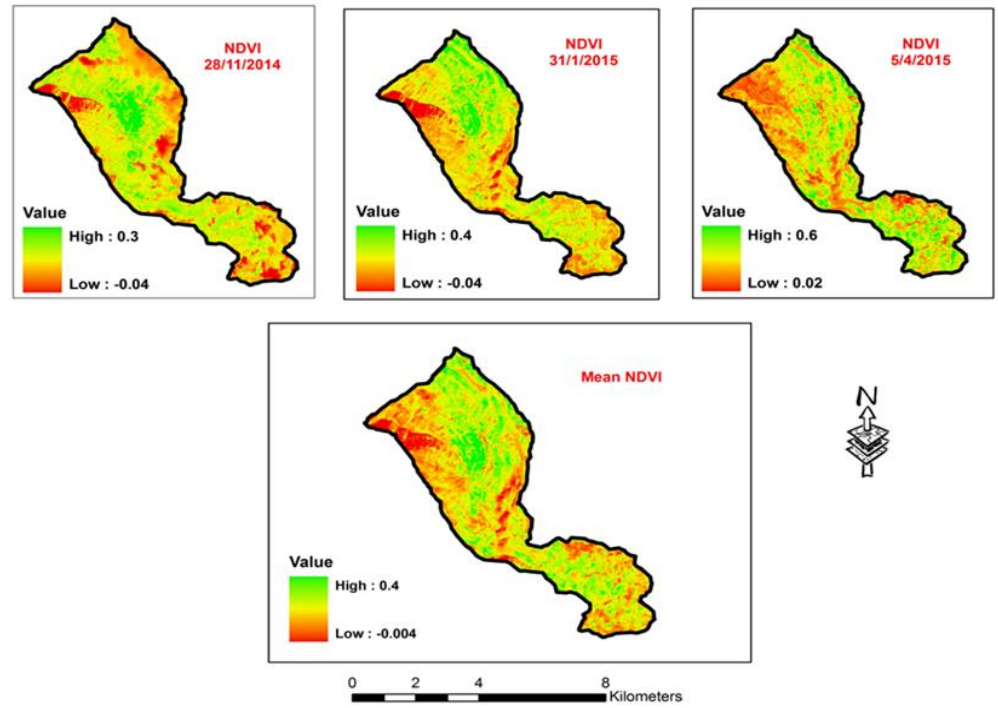

Figure 10: NDVI



Figure 11: $\mathrm{C}$ factor

\subsection{Soil Erosion}

Soil erosion map based on the Revised Universal Soil Loss Equation (RUSLE) was produced as shown in (Figure12). The erosion map shows that the erosion loss varies from $0-1170 \mathrm{t} / \mathrm{ha} / \mathrm{yr}$ while the estimated mean erosion loss is $(38.7 \mathrm{t} / \mathrm{ha} / \mathrm{yr})$. 


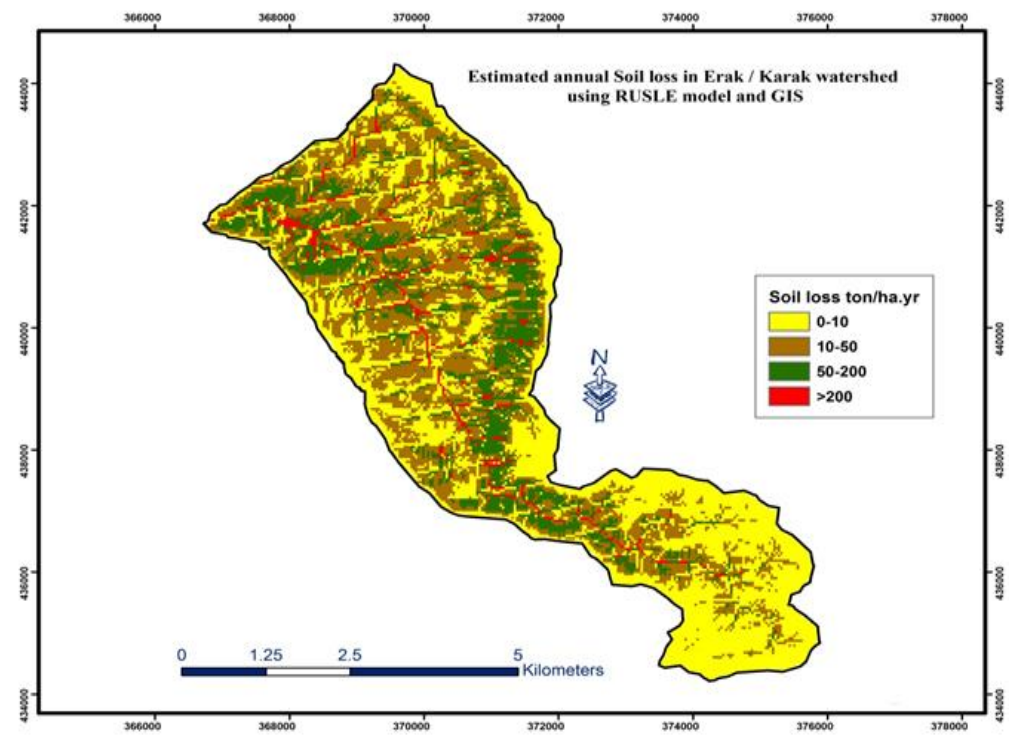

Figure 12: soil erosion map

Soil erosion hazard map was classified based on average annual soil loss rate to four classes: low, moderate, high and very high (figure13).

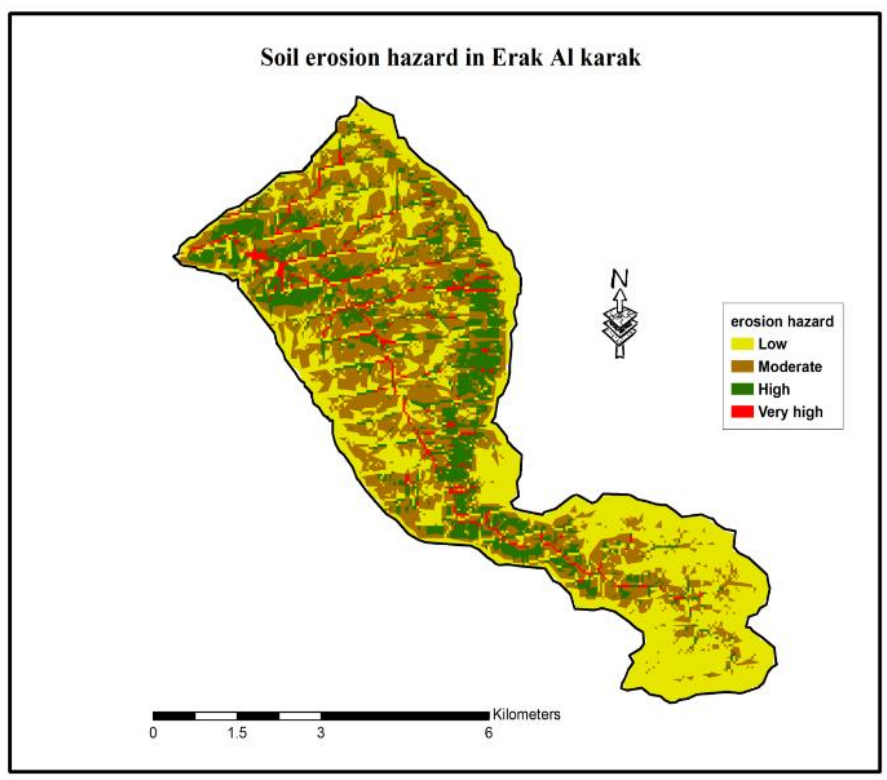

Figure 13: soil erosion hazard

Table 2 shows that $43 \%$ of study area is classified as low erosion hazard and $36.25 \%$ is moderate due to low values of LS factor that is highly affected by slope degree and flow accumulation. Almost $20 \%$ of the study area are classified as high and very high soil erosion rate which indicate that these areas are suspected to fast land degradation unless some support practices are applied. These areas have high soil erosion values due to high values of LS, R, C factors and low plant cover. 
Table 2: area percentage of erosion hazard classes

\begin{tabular}{|l|l|l|}
\hline Erosion hazard & Soil loss rate (t/ha/yr) & Area percentage \\
\hline Low & $<10$ & 43.15 \\
\hline Moderate & $10-50$ & 36.25 \\
\hline High & $50-200$ & 17.23 \\
\hline Very high & $>200$ & 3.37 \\
\hline
\end{tabular}

The mean Soil erosion losses per each land use are presented in table 3. The lowest average soil loss was observed in urban areas $(14.52 \mathrm{t} / \mathrm{ha} / \mathrm{yr})$ and terraces $(16.65 \mathrm{t} / \mathrm{ha} / \mathrm{yr})$ while the highest values were obtained from bare rock $(66.73 \mathrm{t} / \mathrm{ha} / \mathrm{yr}))$ and range land $(53.18 \mathrm{t} / \mathrm{ha} / \mathrm{yr})$.

To examine the impact of terraces on reducing soil erosion, two maps were produced with and without terraces. Analysis show that terraces reduced the soil erosion by $22 \%$ significantly as shown in table (3).

Table 3: effect of terraces on mean soil losses

\begin{tabular}{|l|l|l|}
\hline Landuse & Mean with terreces $(\mathbf{t} / \mathbf{h a} / \mathbf{y r})$ & Mean without terreces (t/ha/yr) \\
\hline Urban areas & 14.52 & 14.52 \\
\hline Rainfed & 17.70 & 17.70 \\
\hline Bare rock & 66.73 & 66.73 \\
\hline Terraces & 16.65 & 21.55 \\
\hline Rangeland & 53.18 & 3.18 \\
\hline Low forest & 30.70 & 30.70 \\
\hline Irrigated agriculture & 37.85 & 37.85 \\
\hline
\end{tabular}

\subsection{Hot Spot Areas}

Figure (14): shows the hot spot areas susceptible to high soil erosion (high \& very high). Special attention should be applied to the hot spot areas to reduce land degradation and to protect these areas from further deterioration.

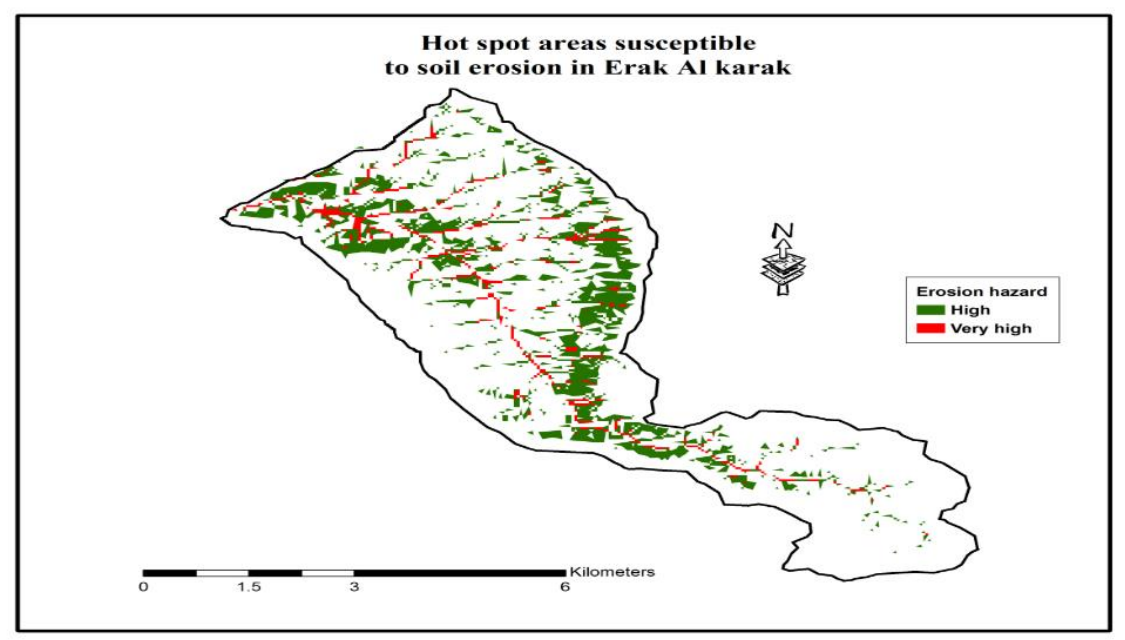

Figure 14: hot spot areas 
table (4): shows that most of the hot spot areas are located in the rangeland and bare rock as $63 \%$ and $21 \%$ respectively. While Agricultural lands are responsible for $14 \%$ of the hot spot areas. The results emphasis the importance of urgent land use planning and conservation practices to be applied on areas of rangeland and bare rock.

Table 4: area percentages of contributing land use to hot spot areas

\begin{tabular}{|l|l|l|}
\hline Land use & Area $(\mathbf{m})$ & area $(\%)$ \\
\hline Bare rock & 1.20 & 20.97 \\
\hline Irrigated agriculture & 0.11 & 1.88 \\
\hline Low forest & 0.00 & 0.07 \\
\hline Rainfed & 0.67 & 11.66 \\
\hline Rangeland & 3.62 & 63.31 \\
\hline Terraces & 0.06 & 1.00 \\
\hline Urban areas & 0.06 & 1.10 \\
\hline
\end{tabular}

\section{Acknowledgment}

The authors acknowledge Dr. Feras Ziadat from FAO for his valuable assistance and contribution provided to estimate RUSLE factors.

\section{References}

[1] Khresat, S., 2006. Major Causes of Land Degradation and Desertification in Jordan. Proc. 18th World Congress of Soil Science July 9-15, 2006 - Philadelphia, Pennsylvania, USA.

[2] Ministry of Environment. 2006. Environmental Profile of Jordan 2006.

[3] National Strategy and Action Plan to Combat Desertification Land Degradation in Jordan - Review of Knowledge Resources 2012.

[4] M. Minwer Alkharabsheh Et Al., Impact of land cover change on soil erosion hazard in northern Jordan using remote sensing and GIS Procedia Environmental Sciences 19 (2013) 912 - 921.

[5] Y. Farhan Et Al. Spatial Estimation of Soil Erosion Risk Using RUSLE Approach, RS, and GISTechniques: A Case Study of Kufranja Watershed, Northern Jordan Journal of Water Resource and Protection, 2013, 5, 1247-1261.

[6] Lubna S. Qaryoutietal, Et Al., Gis Modeling of Water Erosion in Jordan Using "Rusle" Assuniv. Bull. Environ. Res. Vol. 17 No. 1 March 2014.

[7] Brooks, K.N., P.F Ffolliott, H.M. Gregersen, and L.F. Debono, 2003: Hydrology and the Management ofWatersheds, 3rd Edition. Iowa State Press, Ames, Iowa.

[8] Renard Kg, Foster Gr, Weesies Ga, Porter Jp. Rusle: Revised Universal Soil Loss Equation. Journal of Soil and Water Conservation 1991; 46(1):30-33.

[9] Wischmeier, W.H. and Smith, D.D. (1958). Rainfall energy and its relationship to soil loss. Transactions, American Geophysical Union 39: doi: 10.1029/TR039i002p00285. issn: 0002-8606.

[10] Simms AD, Woodroffe CD, Jone BG. Application of RUSLE for erosion management in a coastal catchment southern NSW. http://ro.uow.edu.au/scipapers/34/2003

[11] Eltaif N. I., M. A. Gharaibeh, F. AL-zaitawi and M. N. Al hamad, 2010: Approximation of Rainfall Erosivity Factors in North Jordan, pub. Elsevier, Pedosphere 20(6): 711-717.

[12] Wischmeier, W. H., and Smith, D. D. (1978). Predicting rainfall erosion losses. Agr. handbook No. 537, U.S. Dept. of Agr., Science and Education Administration.

[13] Wischmeier, W.H., C. B Johnson, and B.B.Cross. 1971: A soil erodibility nomograph for farmland and construction sites. Journal of Soil and Water Conservation 26:189-193. 
[14] Renard, K.G., Foster, G.R., Weesies G.A., et al. (Coordinators). (1997) Predicting Soil Erosion by Water: A guide to conservation planning with the Revised Universal Soil Loss Equation (RUSLE).

[15] Van der Knijff JM, Jones RJA, Monta narella L. Soil erosion risk assessment in Italy. European Soil Bureau http://139.191.1.96/ESDB_Archive/pesera/pesera_cd/pdf/er_it_new.pdf. 1999.

[16] Mhangara, P., Kakembo, V. \& Lim, K. J. 2012. Soil erosion risk assessment of the Keiskamma catchment, South Africa using GIS and remote sensing. Environmental Earth Sciences, 65(7), 2087-2102.

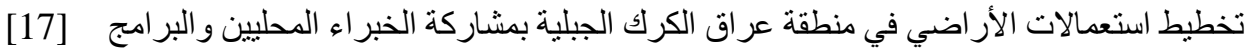

التنموية باستخدام "نظم المعلومات الجغر افية". صفاء مز اهرة , ماجد البصول , فراس زيادات, دعاء أبوحمور 2015 [18

*Corresponding author.

E-mail address: s_mazahreh@yahoo.com 